\title{
NEXUS: A School Based Approach to creating a Centre for Advancing Learning Excellence.
}

Suzanne Downes

Director of Nexus The Hills Grammar School

Australia

Tania Maley

Research Librarian

The Hills Grammar School

Australia

Stephen Liseo

Head of ICT Integration

The Hills Grammar School

Australia

The restructuring of the Library at The Hills Grammar School in 2007, has provided a broader concept that links and connects the whole school community (students, teachers and parents) through research, knowledge and learning involving a wide range of collaborative practices and information communication technologies. A deliberate renaming of both the Library to NEXUS and the title of the Teacher Librarian 7-12 to Faculty Liaison Teacher Librarian was necessary to intentionally shift the mindset of staff away from the traditional Library paradigm to reflect the collaborative nature of the newly established centre and to provide the catalyst for change.

ICT Integration; collaborative practices; learner-centric teaching

\section{Introduction}

The Hills Grammar School, located in Sydney's northwestern suburbs, is an independent, K-12, co-educational, non-denominational school with an enrolment of approximately 1200 students. The school's mission is to be a national leader in co-education, 
at the forefront of educational endeavour, where each student is encouraged to strive for excellence in scholarship, personal development and citizenship.

In moving towards this realisation, a review of our K-12 Library was conducted in 2006 to measure the strength of our school library as compared to other competitive leading independent schools in Sydney. The findings highlighted the falling use of the facilities and resources in our library by both senior school (Years 7-12) students and staff and a real need to move forward to meet the ever increasing challenges of education in the $21^{\text {st }}$ century. Some research suggests that the impact of the school library diminishes as students move through high school (Burks 1999; Lance 2001b). As a result, the unique opportunity arose to make a positive intervention designed to enhance student learning and raise the profile of the school library. At the start of the 2007 school year, with the Principal's full support for the initiative, the Library Department was restructured to include specialised Information Technology services, by combining the expertise and provisions of the existing Library with those of the ICT Department. This new vision, to replace the old Library paradigm, involved the establishment of a centre, NEXUS, to focus on new ways of learning, knowledge creation and research skills while maintaining library services as a component. The programs currently on offer within NEXUS include:

K-4 Library Program

Information Literacy Years 5-12

Information Technology Integration Years 7-12, including Multi-Media

Professional Learning K-12

Scholarship Program Years 7-12

Careers and Tertiary Awareness

Online Learning

As the school library research builds, we see strong and compelling evidence that school libraries are engaging places in the lives of our students, and at the same time we see challenges ahead where much needs to be done. These challenges take us beyond traditional notions of the 3 R's (reading, writing, and numeracy), as long standing conceptions of information literacy. They focus our thinking on building a knowledge-based society, and the understandings and actions that will enable our students to get there. The challenge for us is to shift the emphasis from information centric to embrace a powerful vision of knowledge centric. This is a whole school approach with support needed by all stakeholders to ensure the best learning opportunities are provided for our students. This paper focuses on exploring the pedagogical challenge presented: how can we achieve this?

\section{Rationale}

In order to facilitate curriculum practices which establish closer connections and collaborative practices between Library services and classroom teachers, NEXUS has integrated ICT into teaching programs to strengthen resource-based enquiry learning by promoting active learning through students' confrontation with information resources. This 
integrated approach allows us to guide students meaningfully through their information inquiries to develop deep knowledge and deep understanding of their topics.

Information communication technology (ICT) provides unprecedented opportunity for collaboration, autonomous work and cross-curricular projects. The knowledge economy dictates that we, as educators, need to continually remain informed of new technologies and their implications in the educational environment. We are entering a new interconnected, networked world where more and more people are gaining access to the Web and its ever growing body of knowledge. Its effects, in an educational context, inspire and challenge us, as teachers, to think differently about our classrooms and the potentials of the new digital technologies in terms of pedagogy and curriculum. Research acknowledges the work of the classroom teacher is greatly enhanced when they can collaborate with an information specialist in their planning of curriculum and associated assessment tasks. A major component of this ICT Integration program has been the professional development and training of staff in the planning, preparation and presentation of lessons using blogs, forums, wikis, podcasts and many of the emerging Web 2.0 technologies. Liseo has been able to measure and monitor the levels of skill development and subsequent integration of ICTs into program development of the participating staff at The Hills Grammar School. Teachers have to be prepared for questions relating to students' ICT use and those that related specifically to the subject content whilst applying Information Literacy elements to their work. This increase in knowledge, skills and understanding shows direct transference into the variety of new learning opportunities these teachers can now provide to cater for the diverse range of student abilities and learning styles of their students. It also underpins all teaching and learning programs as teachers see ways to directly link ICT integration to syllabus outcomes and assessment tasks. It is this shift in thinking that has been so exciting and rewarding. From the outset, it was recognised that in order to be successful, we had to take a collaborative approach to teaching and a constructivist approach to learning. There is no doubt that constructivism has had a marked impact on teaching and learning practice. This theory suggests that in learning, students build on what they already know and actively immerse themselves with a range of resources.

To support the notion of strong collaboration, the job description and subsequent title of our traditional teacher librarian (Teacher Librarian 7-12) was intentionally restructured to typify the more contemporary and evolving role of faculty liaison. Through this partnership, our newly titled Faculty Liaison Teacher Librarian is in a better position to identify opportunities for learning and improve access to information. The shift from a content-based education to an outcomes-based education also moves the focus from what students have been taught to what they have learned in terms of knowledge, skills and understandings. These changes in approaches to teaching and learning have required school librarians to adopt a more outcomes-focused practice and a focus on information literacy as opposed to a collections-based practice. Incorporating the role of Head of ICT Integration into the traditional Library paradigm has led the shift away from the stereotypical input such as, isolated library skill sets, selection of general resources, audiovisual facilities towards more meaningful input into user needs through information literacy and inquiry, multimedia and the development of new digital literacies, collaboration and curriculum integration. Students need to be actively involved in discovering and constructing their new understandings to meet both the curriculum outcomes and content standards.

To provide this collaborative context for the delivery of educational programs and to address the falling use of the Library by senior school students and staff, students in Years 79 were allocated a mandatory fortnightly lesson in NEXUS as either an additional English 
lesson (Year 7) or Science lesson (Years 8/9) per timetabled cycle. This has allowed NEXUS Centre professionals and teachers to work together to integrate information resources and ICTs into their teaching programs. It was agreed that information literacy does not exist in a vacuum and for real learning to occur, information skills must emerge from the subject areas in which they are embedded. Information literacy provides the framework for recognising the need for, locating, evaluating and using information. Information literacy is the ability to confidently define, locate, and critically use information across a broad range of information sources and technologies. By working collaboratively, our goal was to bring together the specialised skills of the information professionals with the rigorous subject understandings and disciplinary knowledge and skills of classroom teachers.

An Action Research model was used to evaluate the success of establishing a collaborative working environment between subject teachers and NEXUS professionals for Year 7 English students. Further to the collaborative study, is the creation of assessment tools for tracking and assessing student learning outcomes in information literacy skills. This has led to the development of an operational skills program that can be utilized across faculties and will verify the success of the collaboratively devised information literacy program. Whilst we have established a Centre to advance learning excellence, we are mindful that we are merely a 'connection' or 'link' to what is happening in the classroom and in the computer lab. NEXUS is a springboard from which to leap into collaboration and best teaching practice whilst concurrently, raising the profile and prestige of our often under-rated library professionals.

\section{Methodology}

Having identified a need for pedagogical change, to determine the success of these jointly planned, integrated Literacy lessons and whether there had been any significant growth in information literacy skills development, an Action Research methodology was used. We chose this methodology as it is often used in education to review existing practice with the view to improvement and is a tool frequently used to facilitate change. Being a cyclic process where action and critical reflection occur in turn, it afforded the opportunities to explore and test new ideas and assess the effectiveness of these. With the Year 7 English classes, the focus was more so, to determine the change in student learning whereas with the Years 8/9 Science classes, the aim was to determine the change in the delivery and mode of teaching, whilst recognizing that both areas overlap.

Schutz (2006) discusses Action Research as a valuable tool that indirectly improves student learning outcomes in information literacy. The report focuses on teaching staff gaining an understanding of the importance of collaboration between themselves and Library staff and the need for them to familiarise themselves with information literacy skills. These findings directly relate to this research which has found many teachers are uncomfortable with the teaching of information literacy and do not recognise the significance of information literacy skills as a prerequisite for lifelong learning.

Todd (2001) states the importance of Action Research in school libraries as a crucial tool for raising the profile of the Library/Information Services centre. This, too, is an important outcome for NEXUS. Todd (2002a, 2002b, 2002c) makes a strong case for librarians to undertake action research of their own, focusing on the key question of how the quality of student learning in their particular schools could be improved. 


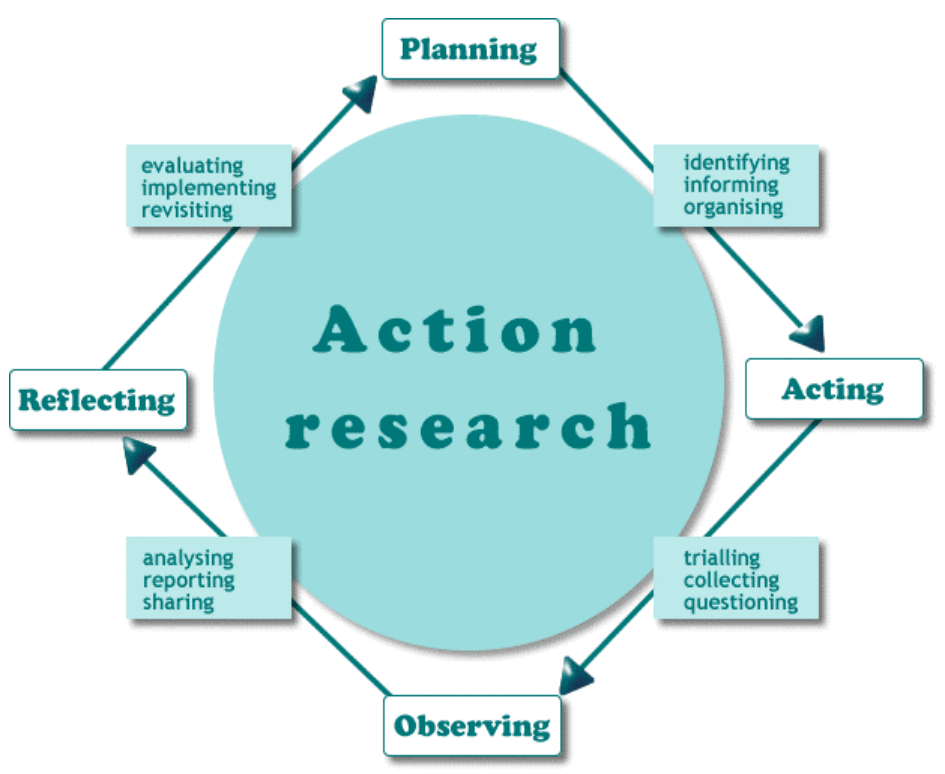

Action Research Model

Department Education \& Training https://www.det.nsw.edu.au/proflearn/research/actres.htm

Action Research is a social process for research, learning, action and reflection where the author acts as a Process Consultant, engaging in dialogue to encourage participants' cooperation, active participation and self-reflection according to Zuber-Skerritt (1991) and Masters (Masters, 2001).

This project draws on the practical application of Action Research which involves changes to the participants' awareness as well as change in social practices.

The following outline for Action Research is based on 'A thematic concern and four moments of Action Research', whereby four fundamental aspects of Action Research were identified for this study:

The development of a critically informed action plan is essential to improve existing practices because it provides an environment that supports collaborative practices through theoretical and practical discussion. The anticipated outcome will be a shared discourse in which participants can analyse the situation to further develop and improve their knowledge and actions.

The Action Plan is implemented as a controlled practice. The action taken is observed and analysed which then forms the basis or starting point for developing the program. The plan needs to take into account the progressive needs of the students and teaching staff. Therefore, the plan needs to be suitably flexible and adaptive to accommodate any unanticipated outcomes. Risks that need to be considered include the potential effects of social change on existing teaching programs and classroom practice; and, the political dynamics which may arise within faculties and also between NEXUS professionals and teaching staff. A journal should be maintained throughout this process to record feelings, ideas, experiences, attitudes, comments and unexpected observations. 
A critical aspect of Action Research depends on the researcher(s) being aware of the intended consequences and thus able to consider any unintended consequences, circumstances and constraints that arise from even the best planned Action Research implementation. Reflection on implementation needs to be followed by thoughtful discussion of how to further develop the plan to improve existing practices.

Of the five Year 7 English classes, specifically timetabled into NEXUS for one lesson per fortnight, four were selected for this study. This cohort numbered close to 100 students however, the top Honour class students were not involved. The methodology used for this research is based on the NSW Department of Education's, 'Exploring a standards-referenced approach for assessment in the new HSC-School based program in the school with a

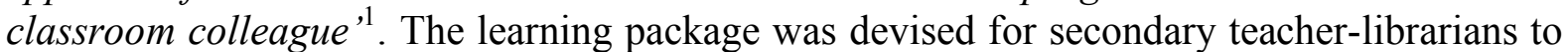
engage with the information supporting Assessment for the New HSC. The aim of the NSW Department of Education is to undertake a collaborative project based on the principles of action learning to develop quality assessment tasks for Stage 6 (Years $11 \& 12$ ). For the purpose of this study, this model was used as a guide and adapted for our use with Stage 4 (Years $7 \&$ 8) students.

The approach was to embed the teaching of Information Literacy skills, as prescribed by the NSW Board of Studies English syllabus, into the class teacher's subject content and related assessment tasks, using the abovementioned NSW Department of Education assessment framework. The inclusion of information literacy skills development in teaching programs within schools is now a stated requirement in all Key Learning Area curriculum documents by the NSW Board of Studies (BoS). Unfortunately, the BoS has not provided any guidelines that define information literacy. The Council of Australian University Librarians (CAUL) published an accepted definition of information literacy for educational institutions, including secondary schools, which has been adopted for the purpose of this paper. The CAUL (2001) definition of information literacy is when a person is able to:

Recognise a need for information

Determine the extent of information needed

Access the needed information efficiently

Evaluate the information and its sources

Incorporate selected information into their knowledge base

Use information effectively to accomplish a purpose

Understand economic, legal, social and cultural issues in the use of information

Access and use information ethically and legally

Classify, store, manipulate and redraft information collected or generated

Recognise information literacy as a prerequisite for lifelong learning.

\footnotetext{
${ }^{1}$ http://www.schools.nsw.edu.au/schoollibraries/teaching/schfocus.htm. (accessed on 23/08/2007)
} 
To measure and evaluate the improvement in the students' levels of information literacy skills through collaborative planning, programming and teaching of lessons between the Year 7 English teacher(s) and assigned NEXUS teaching staff, and to concurrently measure the effectiveness of the teaching and the improvement in student learning outcomes, a tool was devised by Maley, as part of her Master of Knowledge Management research, to assess students' entry and exit information literacy skills based on the assumption that information literate students understand how knowledge is organised and how to effectively use information to learn. (This cohort will be tracked and monitored in subsequent years).

The objectives of the project were:

To identify and extrapolate the relevant Information Literacy standards component of the Stage 4 English Syllabus curriculum outcomes and integrate these with the lesson content;

To devise a defined set of marking criteria to assess Year 7 students' Information Literacy skills (pre- and post-instruction);

To conduct an evaluative study to monitor and track any significant changes to Year 7 students' Information Literacy skills.

To identify the elements that support successful collaboration between colleagues.

Following discussions with the then Head of Teaching \& Learning 7-12 (also Technology teacher for Years 7-12 and former Head of Technology \& Applied Sciences), it was noted that Year 7 students were already technologically savvy upon entry to Senior School and in many cases, their level of Information Technology literacy surpassed the Board of Studies (BoS) outcomes. From these initial discussions, it also emerged that classroom teachers were not comfortable with teaching information literacy because they did not understand its context and could not integrate the skills into their subject outcomes. Given their confusion, it is unlikely that successful programs could be developed in isolation by either classroom teachers or indeed, teacher librarians. It became apparent that programming needed to be constructed in joint collaboration with clearly defined information literacy standards to be taught.

Kuhlthau and Todd (1996) discuss guided inquiry as a carefully planned approach to teaching conducted by teachers and librarians. This approach pre-supposes that collaboration is an established part of the teaching process. The theory of guided inquiry, in practise, will be a deeper collaborative approach between classroom teachers and NEXUS staff. Guided inquiry is planned, supervised targeted intervention by an instructional team of school librarians and teachers who guide students through curriculum units that build meaningful knowledge that steadily leads to independent learning (Kuhlthau 2007). Gawith (2005, as cited in Heinstrom \& Todd) discusses inquiry learning as encouraging students to ask questions, discover new ideas and critically analyse their findings.

\section{Collaborative Practices}

The Action Research model commenced with initial discussions between the English Faculty (Year 7 English teacher) and the Research Librarian at the beginning of the school year to decide on how best to meet the integrated Stage 4 outcomes for English and 
Information Literacy. The key objective of the initial round of assessments was to determine the base level of information literacy skills of the incoming Year 7 students so that a specific program could be devised with incremental levels of proficiency to increase students' skills, taking into account the students' intellectual growth and maturity over the school year. Concurrently, marking criteria for assessment had to measure the students' information literacy skills development against their intellectual growth and maturity over the school year.

Of the five Year 7 English classes, the Honours class (comprising gifted and talented students in Humanities) was not involved in these assessments. This class worked from a differentiated curriculum, at an accelerated level and as the NEXUS Information Literacy (IL) program did not meet their specific needs, the integration of IL outcomes for the Honours class was the task of their assigned English teacher. The four other English classroom teachers supported their students' participation in the collaborative program.

Heinstrom and Todd (2006) discuss the importance of identifying an approach to a curriculum topic that students can relate to and as a consequence, are motivated to increase their depth of learning. Therefore, the collaborative process between the classroom teacher(s) and Nexus professional(s) was to develop rich tasks to stimulate, motivate and improve student learning. Teaching students in a technology environment provided a comfortable and familiar platform from which to launch into inquiry learning. The guided inquiry approach used in this Action Research report meets with content and standards requirements as set by the Board of Studies. The syllabus states:

'English in Years 7-10 is both challenging and enjoyable. It develops skills to enable students to experiment with ideas and expression, to become active, independent learners, to work with each other and to reflect on their learning.'

A critical question that needs to be defined and answered is what exactly do we mean by 'collaboration'?

Collaboration is a network of interdependent elements and is explained in the concept of curriculum alignment (CAUL, 2001). The 'web of consistency' can be applied to any discipline and/or topic area and information literacy skills can be assessed within that context. Collaboration has a truly great effect on improving students' academic learning when innovation coupled with creativity is applied to the mix.

The model below can be used to represent collaboration and the elements that support successful collaboration.

Curriculum Alignment Model

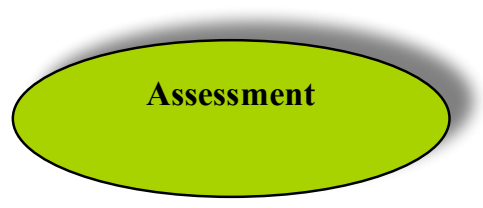




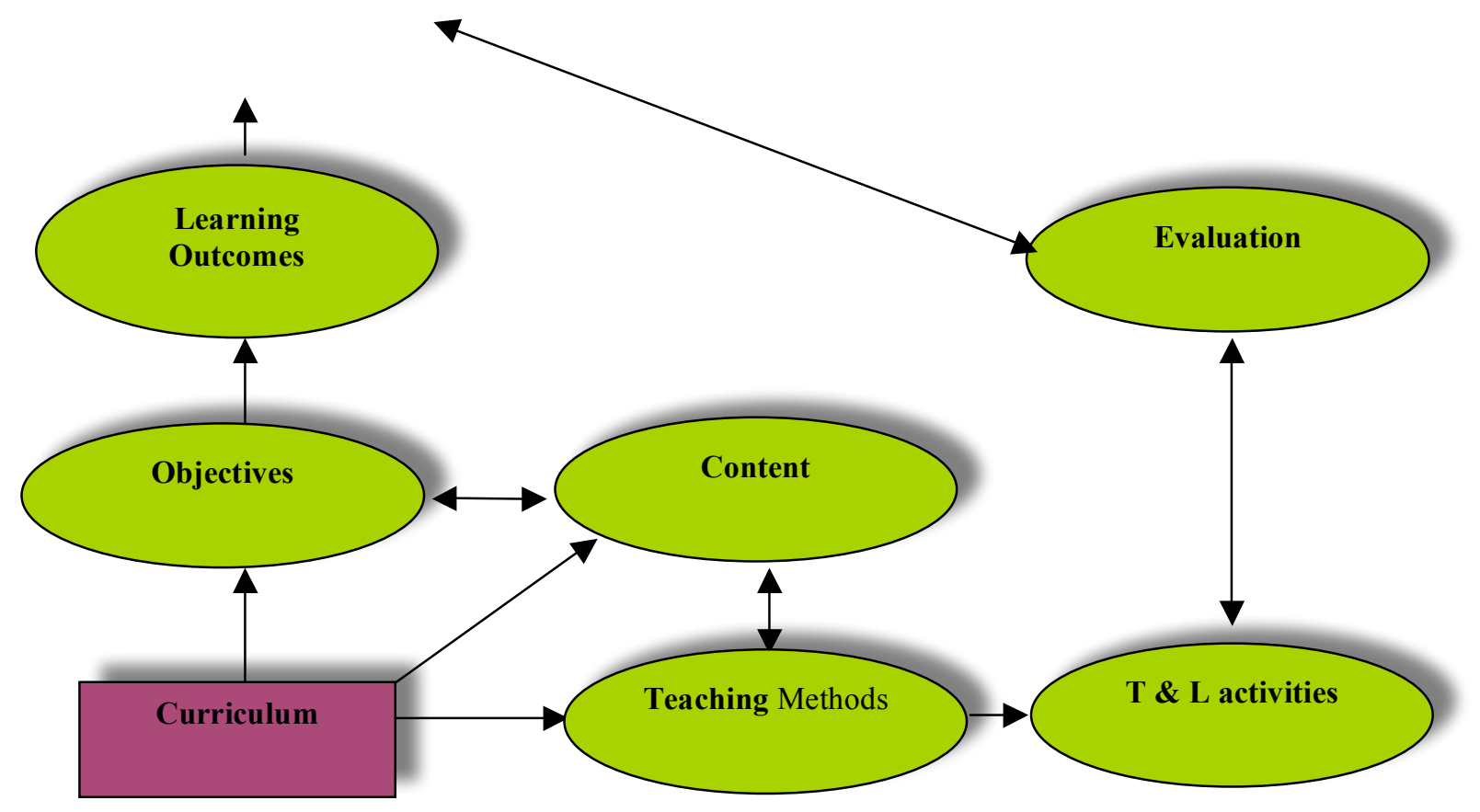

Figure : The curriculum alignment model displays the alignment between goals, objectives, content, learning outcomes, teaching methods, teaching and learning activities, assessment and evaluation relevant to collaboration in education (CAUL, 2001).

The theories advocated in the literature reviewed for this project highlighted the benefits of collaborative teaching between subject teachers and NEXUS professionals which include but are not limited to:

A positive attitude to the inclusion of and the teaching of Information Literacy skills in their English teaching programs by the classroom teachers

Motivation and support for classroom teachers to take responsibility for their own professional development in the use of and integration of ICTs in their teaching programs

A desire to develop rich learning tasks and deep learning outcomes through resourcebased learning tasks to motivate students and improve student learning outcomes

The opportunity this provides to showcase the facilities and programs on offer within NEXUS to the wider School community thus raising its profile. 


\section{Administration of Assessment Tasks}

\section{Assessment Task 1}

This first assessment task was designed to focus on how well the students identified and retrieved information and was conducted in Week 3 of Term 1. The information the students were asked to find was based on the Year 7 Scope and Sequence strand 'Growing Up', covering difference and diversity. In English, they were studying the novel, 'Little Brother', by Allan Baillie (1995) which provided the context for the program. Students had two one-hour lessons in which to complete their task.

The first assessment was administered to the four Year 7 English classes by their assigned English teacher and the Research Librarian who, together, team teach these fortnightly Literacy lessons. After analysing the results of the initial assessment task, some Year 7 teachers were not as enthusiastic as they had earlier been. Their concerns were that their students were not able to understand all the questions, for example, the instruction to locate different websites ending with .org or .edu. Another teacher was unsure about the amount of time it would take to complete the task, feeling it would take longer than the two lessons allocated, and expressed their concern that the students would lose focus. Most teachers were interested to observe their students' behavioural and assessment outcomes at the culmination of the second lesson, and keen to learn how able they were at identifying and retrieving information. The marking of the assessment task was divided into two sections, with the core English content being marked by the subject teacher and scores recorded before the Research Librarian marked the Information Literacy component. These marks were not recorded on the students' assessment but instead used to determine the baseline level of information literacy skills that would enable collaborating teachers in the English faculty and NEXUS staff to design an IL Program for Year 7 entry.

The assessment task comprised three levels of scoring: Developing, Satisfactory and Achieving. Students who failed to answer the question correctly or whose answers did not address the question were put into the Developing category, requiring further support (preferably one-to-one intervention). Those who were able to partially answer the question, demonstrating an understanding but giving an incorrect response, were marked Satisfactory. Students who answered the question correctly and were able to give an example from the text were awarded Achieving. The criteria for marking the assessment task was based on the combination of relevant learning outcomes from both the Board of Studies Stage 4 English Syllabus and the CAUL Information Literacy standards. 


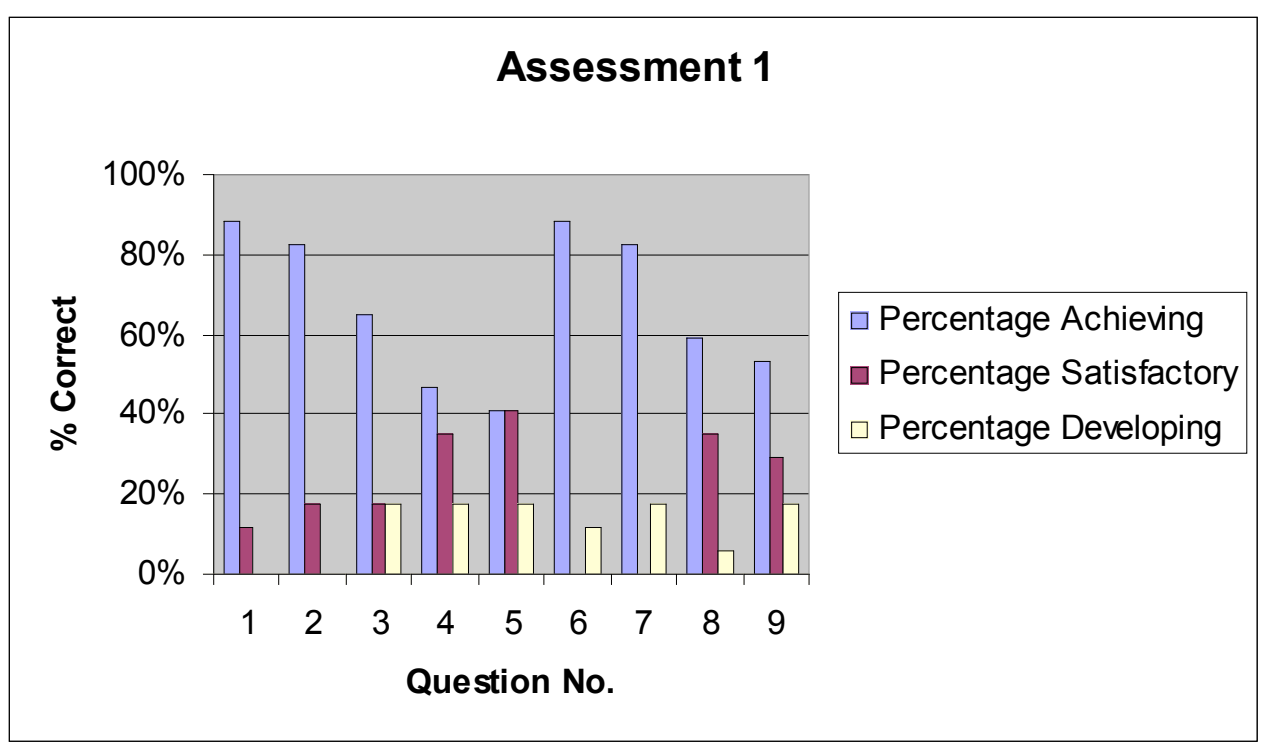

Table 1: Assessment Task 1 Results

A number of interviews with the English subject teachers were held in person and/or via e-mail with the Research Librarian. A template was used for question and answer type dialogue under various headings, such as: What we did; what we learnt about assessment practices for IL; how can this information be shared/used to improve learning and teaching; what refinements would we suggest. The extra work load required by teachers to integrate information literacy skills into their teaching had not been factored into their already busy schedules and teachers were not given any opportunity to program in these new Literacy classes (one per fortnight in NEXUS) before the school year began. A better result would have been achieved if a collaborative plan had been put in place from the outset. Discussion arose about the importance of developing some type of school based Scope and Sequence for the integration of Information Literacy skills into each mandatory THGS curriculum document to track and monitor students' development through each Stage level. Student outcomes would then be reported and accounted for appropriately, giving IL the validity in the School curriculum that it rightly deserves.

The flexibility of the Year 7 Literacy Program, taught collaboratively, offered the opportunity for joint reflection on what had happened and the chance to make necessary modifications before the next round of assessments. As both teaching parties were mindful of the pitfalls that could affect the program, this collaborative approach added to its success. Other feedback included not only the development of positive relationships between teachers and NEXUS staff but also in smoothing the boundaries between NEXUS, as a teaching and learning environment and the classroom for both students and teachers. Teachers began to see that NEXUS was a further extension of their classroom. The constructivist approach allowed for goal setting, independent and collaborative learning and active learning with the teacher and librarian acting as facilitators rather than deliverers of content.

The first assessment task determined the base level of each student and identified a common weakness in students' ability to critically evaluate websites as information resources. This information directed the focus for teaching and formed the subsequent testing for Assessment Task 2. 
Coinciding with the first round of testing, the Head of ICT Integration, central to the new concept of NEXUS, was conducting training for interested staff on Moodle (an online teaching and learning web interface tool that allows teachers the flexibility to post lessons, assessments and homework online). Moodle provides the opportunity for a 24 hour classroom which, in itself, has brought many new challenges with teaching staff now required to become more information literate. The introduction of Moodle as a teaching and learning tool, combined with the introduction of Information Literacy teaching, has given NEXUS a raised profile within the School community, even at this early stage.

\section{Assessment Task 2}

The guided inquiry approach has a greater application to student learning than knowledge gathering. It is not enough to provide students with sources and instruction in finding and evaluating information. A more holistic approach where an intervention is implemented (by the teacher and the librarian) in the information seeking process will encourage students in their own learning processes. It was anticipated that students would engage willingly in the learning process if they were motivated by the topic and encouraged to complete the task in a supportive learning environment. As evidenced, an area that needed to be developed was the ability to determine the true nature and extent of the information requested and from this, the ability to critically evaluate the information retrieved. A lesson prior to the second assessment task, administered in Week 7 of Term 1, focused on how to differentiate between good and bad websites.
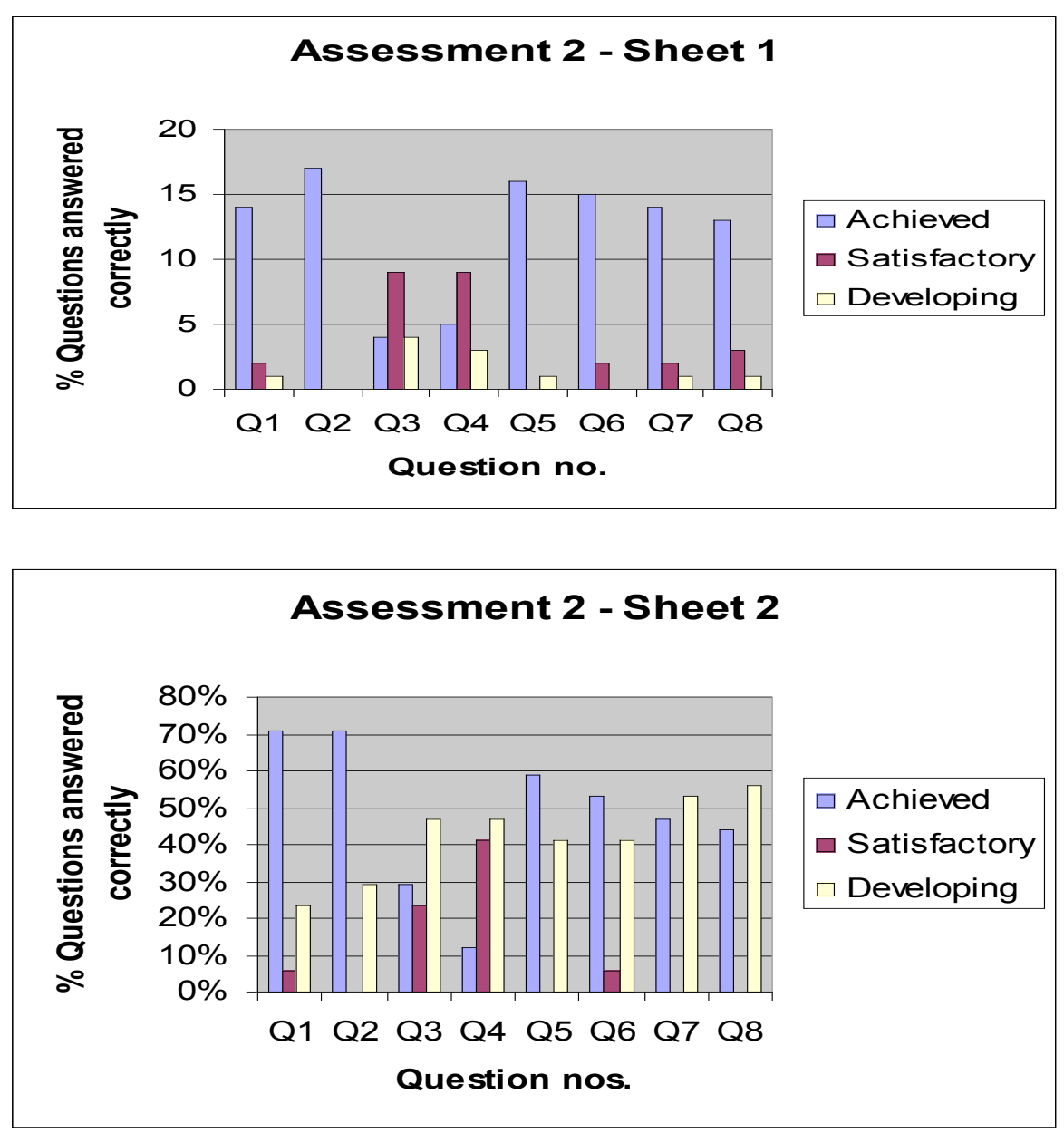
The assessment task was again based on the novel, 'Little Brother', by Allan Baillie (1995) and these questions related to the Board of Studies English syllabus outcomes 1.5 and 1.6 and CAUL Information Literacy Standards 2 and 3. Although some students experienced difficulties identifying elements that define good quality websites and also experienced difficulty critically evaluating information on a website, this assessment task was successful for two teachers who noted that students were able to demonstrate transference of their newly acquired skills to the classroom situation and they were excited about participating in lessons held in NEXUS. Students need to be actively involved in discovering and constructing their new understandings to meet curriculum outcomes and content standards and given opportunities to show transference of their newly acquired skills and knowledge to new situations. The collaborative English information literacy lessons developed an intrinsic motivation to research independently and encouraged positive self-efficacy about accessing and using resources. Not all went smoothly though with the other two groups as one teacher arrived with the class at the beginning of the second lesson and advised the Research Librarian that the class would not be following the planned Information Literacy program. The students were not coping with the online literacy assessment task so the teacher had prepared her own program for the class to follow. The fourth teacher in the program also opted out because the students were finding the tasks challenging and their motivation to finish was extremely low.

\section{Assessment Task 3}

By this stage, students had undergone two terms of information literacy teaching in NEXUS. The collaborative approach ceased to operate due to staffing changes in both the English Faculty and NEXUS. Whilst there was knowledge sharing between the English Department and NEXUS about the topics students were studying, there was no longer the collaborative approach to program design and delivery of these lessons. Students read the play 'Two Weeks with the Queen' by Mary Morris, adapted from the novel by Morris Gleitzman (1993) for the drama topic and the gender theme. For the final round of information literacy testing, students were given two texts in their information literacy class: a portion of 'Aung-San' by Elizabeth Arnold (2007) and a scene from the play 'Boss of the Pool' by Mary Morris, adapted from the novel by Robin Klein (1993). Both texts shared the same themes as the first two assessment tasks: gender; difference and family.

In Assessment Task 3, students were asked to answer a multiple question activity and open-ended responses about the two text types using the online teaching and learning software, Moodle, which focused on critical analysis skills. As Moodle was new to students, the Teacher Librarian gave a tutorial prior to the assessment task whereby students were given the opportunity to answer two 'dummy' questions as a practice beforehand.

The student outcomes were not as strong as Assessment 2. The majority of students did not understand 'text type' or 'genre' or how to recognize the author's name. These questions met BoS English Syllabus Outcome 1.6 where students need to categorise texts by content, genre, composer and purpose and CAUL Information Literacy Standard 3 that states information literate people are able to summarise the main ideas extracted from information gathered. In discussion, it was evident that English teachers find it difficult to teach Information Literacy as part of their English classes. One reason is because the teacher that students have for their regular English lessons may not necessarily be the same allocated to their class for the extra fortnightly Information Literacy classes. Due to this awkward situation, problems have arisen with consistency and continuity of programs. Some teachers 
are keen for information literacy skills to be taught in conjunction with their subject. However, if there is only one lesson every two weeks, it is difficult to integrate information literacy lessons with what is being taught in the classroom and maintain consistency. The English faculty tend to move through topics within the two week timeframe, so the opportunity for teaching information literacy skills linked to the topic is often lost. One teacher even commented that she did not understand what information literacy was and why it had to be part of the English syllabus. By the third assessment task, signs of political and social change began to impact negatively on the collaborative approach.

\section{Conclusion and Recommendations}

This research project has provided evidence-based practice demonstrating the tangible impacts and outcomes of making sound decisions through the implementation of NEXUS goals. The documentation of the learning outcomes of these collaborative teaching-learning lessons has helped to validate the school library to the wider school community, and the learning that is enabled through it. This study showed that initially teachers were not only unsure about what information literacy meant, therefore unable to plan for its inclusion in curriculum outcomes, but were also somewhat reticent to hand over ownership of their students or the delivery of lessons in a team teaching approach. The number of students assessed in this research project only totalled 19 out of 125 students in Year 7 . By introducing a collaborative approach, teachers were forced to share their valuable teaching time with an Information professional who, unlike the classroom teacher, had no accountability for students' learning outcomes in terms of the assessment and reporting cycle. Hence there was very little incentive for teachers to become part of a program such as this one, where the full responsibility remained with the teacher yet the expectation was for class teachers to entrust their students' learning to someone else. It was evident that teachers were comfortable when using NEXUS facilities to teach their own classes, but were not so comfortable in sharing a collaborative teaching approach where they had to take the full responsibility for information literacy outcomes when they did not understand these themselves. To avoid some of the issues that arose, a professional relationship needs to be established between the faculties so collaboration becomes an accepted part of lesson planning, implementation and evaluation. A major shift in thinking is needed to promote and facilitate such collaborative practice at The Hills Grammar School.

From observation and discussion of this research, there are indications that teaching staff can move forward to embrace change, but the change needs to be supported through School Management. A top down approach will cause shift, not always willingly, but it will impact on existing approaches. This project explores the successes and pitfalls, highs and lows, joy and exasperation of initiating new ways of presenting learner-centric teaching.

The Hills Grammar School is justifiably proud of the fact that every individual in the School is valued. The School caters for a large range of abilities and learning styles among the students. We need to be open to different ways of thinking, processing and interpreting the world. We must observe, listen, have an awareness of current theories and frameworks but not ruled or constrained by them. From our NEXUS team's viewpoint this is the challenge, excitement and frustration of our job. If the cap fits, wear it; if it does not, try a new cap, change the old cap, design a new cap or go bare-headed! In NEXUS, our approach incorporates these considerations and seeks to use the most effective teaching strategies in order to engage each student in his/her learning. 
In an atmosphere of collaboration we can continually encourage the students to expand their capabilities and foster confidence as a learner. We endeavour to demonstrate, through our daily interaction with students, a way of teaching that inspires success and a love of learning that will last them all their lives. 


\section{References}

Bruce, C. (1997). Seven Faces of Information Literacy. AUSLIB Press, Adelaide, South Australia

Burks, F. (1999). 'Student Use of School Library Media Centers in Selected High Schools in Greater DallasFort Worth', School Library Media Quarterly, vol. 24, no 3.

CAUL Information Literacy Standards. (2001). Council of Australian University Librarians, Canberra, ACT

Entwistle, T. (2000). 'Promoting deep learning through teaching and assessment: Conceptual frameworks and educational contexts', paper presented at TLRP Conference, Leicester, UK (accessed 7 September 2007).

http://66.102.1.104/scholar?hl=en\&lr=\&as qdr=all\&q=ache:EAE3GVwRyHMJ:www.tlrp.org/pub/acadpub/En twistle2000.pdf+Tait+Entwistle+education $+\% 22$ ASSIST $\% 22$

Gawith,G. (2005). 'Information Literacy and Inquiry', Good Teacher, Term 1, 2005. In Heinstrom, J \& Todd, R. (ed.) 'Uncertainty and guidance: school students' feelings, study approaches, and need for help in inquiry projects', Scan, vol. 25, no. 3, August, 2006

Gordon, C. (2000). 'Information Literacy in Action', John Catt Educational Ltd, Suffolk, UK

Henri, J and Asselin, M. (eds.). (1999). 'The Information Literate School Community 1: Best Practice', Charles Sturt University, Centre for Information Studies, Wagga Wagga, NSW

Henri, J and Asselin, M. (eds.). (2005). 'The Information Literate School Community 2: Issues of Leadership', Charles Sturt University, Centre for Information Studies. Wagga Wagga, NSW

Heinstrom, J., and Todd, R. (2006). 'Uncertainty and guidance: school students' feelings, study approaches, and need for help in inquiry projects', Scan, vol 25, no. 3. August, 2006

Kuhlthau, C (ed). (1994). 'Assessment and the School Library Media Centre', Libraries Unlimited Inc. Englewood, Colorado

Kuhlthau, C and Todd, R. (2007). 'Guided Inquiry', Centre for International Scholarship in School Libraries (CISSL), Rutgers University, http://www.cissl.rutgers.edu/guided inquiry/introduction.html (accessed 10 October 2007).

Lance, K.C. (2001b). 'Good Schools Have School Librarians: Oregon School Libraries Collaborate to Improve Academic Achievement', Oregon Educational Media Association.

Lunsford, K.J., and Bruce, C. (2001). 'Collaboratories: working together on the web', cited in Henri, J and Asselin M (eds.) 2005, 'The Information Literate School Community 2: Issues of Leadership', in Australian Teacher Librarianship, no. 5, CIS, Wagga, Wagga, NSW

Masters, J. (2001). 'The History of Action Research', Action research e-Reports, 3, Accessed 11 November 2007. http://www.fhs.usyd.edu.au/arow/arer/003.htm

McTaggart, R. (1992). Action Research: Issues in theory and practice, paper presented to Methodological Issues in Qualitative Health Research Conference, Deakin University (accessed 3/10/07). http://www2.fhs.usyd.edu.au/arow/o/m01/rintro.htm

NSW Board of Studies. (2003). 'English Years 7-10 Syllabus', Board of Studies, NSW

NSW Board of Studies. (2003) 'Science Years 7-10 Syllabus', Board of Studies, NSW

NSW Department of Education and Training. School Libraries and Information Literacy, Sydney, NSW (accessed 9 November 2007).

http://www.schools.nsw.edu.au/schoollibraries/teaching/resource.htm 
Oberg, D. (ed.). (2005). 'School Libraries Worldwide: Theory, Research Practice'. International Association of School Librarianship (IASL), Zillmere, Queensland

Rearick, M., and Feldman, A. (1999). 'A Framework for Understanding Action Research' (accessed 2/11/07) http://www.unix.oit.umass.edu/ afeldman/Action ResearchPapers/RearickFeldman1999.PDF

Schutz, H. (2006). 'Building Information Literacy: an Action Research Approach', Scan, vol. 25, no. 4, November 2006

Todd, R. (1996). 'Independent Learning and Information Literacy: An Essential Information Partnership for Learning', Learning Resourcefully in the Information Age, AUSLIB Press, 1996, pp. 13-18.

Todd, R. (2001). 'Transitions for Preferred Futures of School Libraries', keynote paper International Association of School Librarianship (IASL) Conference, Auckland, New Zealand, Virtual Conference Session, http://www.iasl-slo.org/virtualpaper2001.html (accessed 8 September 2007).

Todd, R. (2002a). 'Evidence Based Practice: Getting into the Action', Scan, vol. 21, no. 2, May, pp. 34-41.

Todd, R. (2002b). 'Evidence Based Practice: The Sustainable Future for Teacher-librarians', Scan, vol. 21, no. 1 , February.

Todd, R. (2002c). 'School Librarians as Teachers: Learning Outcomes and Evidence-based Practice', $68^{\text {th }}$ IFLA Council and General Conference, Glasgow, August 18-24.

Zuber-Skerritt, O. (1991). 'Action Research for Change and Development', Aldershot, England

\section{Statement of Originality}

This statement certifies that the paper above is based upon original research undertaken by the author and that the paper was conceived and written by the author(s) alone and has not been published elsewhere. All information and ideas from others is referenced. 